\title{
Mechanical Properties of Polymeric Composite Based on Aluminium Microparticles
}

Miroslav Müller, Jan Cidlina, Karolína Dědičová, Alena Krofová

Faculty of Engineering, Czech University of Life Sciences Prague. Czech Republic. E-mail: muller@tf.czu.cz, cidlina@tf.czu.cz, caroline.dedicova@gmail.com, krofovaa@tf.czu.cz.

The paper deals with the testing of composite materials based on aluminium microparticles. The aim of the research was to determine the influence of content of aluminium microparticle filler on the mechanical properties of the polymeric particle composite. The object of the experiments was a particle polymer composite, whose continuous phase was in the form of a two component epoxy resin and a discontinuous phase (reinforcing particles) of aluminium microparticles, which size was less than $45 \mu \mathrm{m}$. The influence of a tensile stress, an impact strength and a wear was experimentally investigated. Composite systems with a higher content of microparticles of aluminium from 15 to 25 volume \% achieve higher values of the tensile strength at higher temperatures of environment than the composite systems with a lower content of the aluminium microparticles (or matrix). Due to the increased temperature of the environment there is a significant decrease in tensile strength. Impact strength showed increased values in composite systems that have a higher percentage of aluminium microparticles. The filler in the form of aluminium microparticles is detrimental to wear resistance. The results show that increasing the concentration of microparticles of aluminium increases the mass losses of the test materials.

Keywords: Al filler, impact strength, temperature, two-component epoxy adhesives, wear

\section{Acknowledgement}

This paper has been done when solving the grant IGA TF (2015:31140/1312/3106 and 2015:31140/1312/3107).

\section{References}

[1] VALÁŠEK, P. (2014). Long-term degradation of composites exposed to liquid environments in agriculture. In: Scientia Agriculturae Bohemica, Vol. 3, No. 1, pp 187-192.

[2] VALÁŠEK, P. (2014). Mechanical properties of epoxy resins filled with waste rubber powder. In: Manufacturing Technology, Vol. 14, No. 4, pp. 632-637.

[3] VALÁŠEK, P. (2015). Polymeric microparticles composites with waste EPDM rubber powder. In: Agronomy Research, Vol. 13, No. 3, pp. 723-731.

[4] RAMAZAN, K., MEHMET, S., BEKIR, Y. (2008). Influence of adhesive thickness and filler content on the mechanical performance of aluminium single-lap joints bonded with aluminium powder filled epoxy adhesive. In: Journal of materials processing technology, Vol. 205. Pp. 183-189.

[5] GALUSEK, D., SEDLÁČEK, J., RIEDEL, R. (2007). Al2O3-SiC composites prepared by warm pressing and sintering of an organosilicon polymer-coated alumina powder. In: Journal of the European Ceramic Society, Vol. 27, No. 6, pp. 2385-2392.

[6] KIM,H. S., KHAMIS, M. A. (2001). Fracture and impact behaviours of hollow micro-sphere/epoxy resin composites. In: Composites Part A: Applied Science and Manufacturing, Vol. 32, No. 9, pp. 1311-1317.

[7] AGOUdJIL, B., IBOS L., MAJESTÉ, J. C., CANDAU, Y., MAMUNYA, YE. P. (2008). Correlation between transport properties of Ethylene Vinyl Acetate/glass, silver-coated glass spheres composites. In: Composites Part A: Applied Science and Manufacturing, Vol. 39, No. 2, pp. 342-35.

[8] MÜLLER, M., VALÁŠEK, P. (2012). Abrasive wear effect on Polyethylene, Polyamide 6 and polymeric particle composites. In: Manufacturing Technology, Vol. 12, No. 12, pp. 55-59.

[9] SHAO-YUN FU, XI-QIAO FENG, BEMD LUKE, YIU-WING MAI, (2008). Effects of particle size, particle/matrix interface adhesion and particle loading on mechanical properties of particulate-polymer composites. In: Composites: Part B, Vol. 39, pp. 933-961.

[10] CHO, J., JOSHI, M.S., SUN, C.T. (2006). Effect of inclusion size on mechanical properties of polymeric composites with micro and nano particles. In: Composites Science and Technology. Vol. 66, pp. 1941-1952.

[11] CHASSER, A.M., MAKHLOUF, J.M., SCHNEIDER, J.R. (1993). Rubber-based structural adhesive is a new option for metal bonding. In: Adhesive Age. Vol. 36, pp. 36-39. 
[12] MÜLLER, M. (2015). Hybrid composite materials on basis of reactoplastic matrix reinforced with textile fibres from process of tyres recyclation. In: Agronomy Research. Vol. 13, No. 3. pp. 700-708.

[13] MÜLLER, M., HERÁK, D., VALÁŠEK, P. (2013). Degradation limits of bonding technology depending on destinations Europe, Indonesia. In: Tehnicki Vjesnik- Technical Gazette, Vol. 20, pp. 571-575.

[14] MÜLLER, M. (2013). Research of liquid contaminants influence on adhesive bond strength applied in agricultural machine construction. In: Agronomy Research, Vol. 11, pp. 147-154.

[15] MÜLLER, M., RUŽBARSKÝ, J., VALÁŠEK, P. (2014). Degradation Process in Area of Connecting Metal Sheets by Adhesive. In: Applied Mechanics and Materials, Vol. 616, pp. 52-60.

[16] MESSLER, R., W. (2004). Joining of materials and structures from pragmatic process to enabling technology. Burlington: Elsevier, 816 pp.

[17] MÜLLER, M., HERÁK, D. (2010). Dimensioning of the bonded lap joint. In: Research in Agricultural Engineering, Vol. 2, pp. 59-68.

[18] ADAMS, R. D., COMYN, J., WAKE, W. C. (1997). Structural adhesive joints in engineering. 2nd ed. Chapman \& Hall, London. 360 pp.

[19] HABENICHT, G. (2002). Kleben: Gundlagen, Technologien, Anwendung. Berlin: Springer. 921 pp.

[20] WEIYHOU JIAO, YOUZHLI LIU, GUISHENEG QI. (2009). Studies on mechanical properties of epoxy composites filled with the grafted particles PGMA/A12O3. In: Composites Science and Technology, Vol. 69, pp. 391 395.

[21] DADFAR, M.R., GHADAMI, F. (2013). Effect of rubber modification on fracture toughness properties of glass reinforced hot cured epoxy. In: Materials and Design. Vol. 47, pp.16-20.

[22] KEJVAL, J., MÜLLER, M. (2013). Mechanical properties of multi-component polymeric composite with particles of Al2O3/SiC. In: Scienty Agriculturae Bohemica, Vol. 4, pp. 237-242. 